\title{
Perbedaan Pertumbuhan Bakteri Shigella dysentriae Pada Berbagai Konsentrasi Perasan Kulit Apel Manalagi (Malus sylvestris Mill) Secara In Vitro
}

\author{
Dita Artanti ${ }^{1}$, Guntari Bekti Lestiana \\ Prodi DIII Teknologi Laboratorium Medik Universitas Muhammadiyah Surabaya \\ 1)dita.artanti3009@yahoo.com
}

Tanggal Submit: 18 April 2018

Tanggal Review: 18 Mei 2018

Tanggal Publish Online:

23 Mei 2018

\begin{abstract}
Manalagi is one type of apple that is consumed by many Indonesian people, because it tastes sweet, tasty, easy to get and the price is quite affordable. The Manalagi apple rind contains some phytochemical derivatives of polyphenols that have antibacterial effects. Shigella dysentriae is a bacillus bacteria that causes acute diarrhea (dysentery) in most people who lack hygiene. One alternative to prevent the disease is to use natural ingredients as an antibacterial. The aim of this research is to know the different growth of $S$. dysentriae bacteria in various concentrations of Manalagi apple rind (Malus sylvestris Mill.) In vitro. The type of this study was experimental consisting of 7 treatments with 4 repetitions. The sample consisted of 7 concentrations of manalagi apple rind $(100 \%, 50 \%, 25 \%$, $12.5 \%, 6.25 \%, 3.125 \%$, and $0 \%$ (control) . The data analysis used ANOVA test with 5\% 0.05). The results showed that the growth of $S$. dysentriae bacteria was only at $0 \%$ concentration; $3.125 \% ; 6.25 \% ; 12.5 \%$; and $25 \%$. While at concentrations of $50 \%$ and $100 \%$ there was no growth of $S$. dysentriae bacterial colonies. The conclusion of this study proves that Manalagi apple rind has antibacterial power against $S$. dysentriae bacteria.
\end{abstract}

Keywords: Shigella dysentriae, Manalagi Apple Rind (Malus sylvestris Mill).

\section{PENDAHULUAN}

Penyakit diare masih merupakan masalah kesehatan masyarakat di Negara berkembang seperti di Indonesia. Diare adalah penyebab kematian yang kedua pada anak balita setelah pneumonia. Diperkirakan 4 milyar kasus diare terjadi setiap tahun pada anak balita di seluruh dunia. Setiap tahun 1,5 juta anak balita meninggal karena diare. Diare membawa kematian lebih cepat pada anak-anak dibanding orang dewasa karena terjadinya dehidrasi dan malnutrisi (Depkes, 2010).

Penyebab yang sering ditemukan di lapangan ataupun secara klinis 
adalah diare yang disebabkan infeksi dan keracunan (Depkes RI, 2011). Sedangkan disentri biasanya disebabkan oleh dua hal yakni disentri basiler yang disebabkan oleh basil dan juga disentri amoeba yang disebabkan oleh parasit Entamoeba histolytica, akan tetapi Shigella $s p$ merupakan penyebab terbanyak terjadinya disentri (Haryadi, 2012).

Shigella merupakan penyebab diare berdarah akut (disentri). Shigella dysentriae berbeda dari serogrup Shigella lainnya karena menyebabkan epidemi besar dan disentri berkepanjangan, lebih sering mengalami resistensi antimikroba dan menyebabkan penyakit yang sering berakibat fatal dari pada infeksi serogrup Shigella lainnya.

Shigella dysentriae merupakan bakteri gram negatif yang berukuran $0,5-0,7 \mu \mathrm{m} \times 2-3 \mu \mathrm{m}$. Bentuknya batang pendek, tidak berspora, tidak berflagel sehingga tidak bergerak, dapat memiliki kapsul. Koloni Shigella cembung, bundar, transparan dengan diameter sampai kira - kira $2 \mathrm{~mm}$ dalam 24 jam (Jawetz, 2008).

Pengobatan yang dilakukan selama ini dengan menggunakan
Trimetoprim sulfametoksazol yang mekanisme kerjanya dengan menghambat sintesis asam folat. Pada penggunaan trimetoprim sulfametoksazol dapat menyebabkan timbulnya megaloblastosis, leucopenia, atau trombositopenia, Kerusakan permanen fungsi ginjal pada pasien yang menderita penyakit ginjal, dan penurunan bersihan kreatinin secara reversible pada pasien yang fungsi ginjalnya normal (Asromedika, 2011).

Oleh karena itu, diperlukan adanya alternatif pengobatan dengan pemakaian tanaman berkhasiat obat yang memiliki sifat bakteriostatik yang dapat menghambat pertumbuhan bakteri tertentu. Alternatif obat yang digunakan adalah Buah Apel.

Apel selain popular dikonsumsi juga memiliki nilai gizi tinggi yang sangat bermanfaat bagi kesehatan, salah satu jenis buah apel di Indonesia adalah apel manalagi (Malus sylvestris Mill). Apel manalagi dikonsumsi oleh masyarakat Indonesia karena rasanya manis, mudah didapat, dan harganya terjangkau. 
Nutrisi penting dari apel sebagian besar berada dilapisan bawah kulit buahnya (Setiawan dkk, 2013). Kulit apel mengandung beberapa fitokimia turunan polifenol antara lain cathecin, quercitin, phloridzin, dan asam klorogenik (Jannata dkk., 2014). Senyawa tersebut memiliki aktivitas antibakteri dengan merusak membran sel, menghancurkan substrat, dan mengganggu fungsi enzim bakteri. Hal yang sama juga disampaikan

oleh

Setiawan dkk., (2013) bahwa apel memiliki khasiat sebagai antiradang, laksatif, astringen, antidiare, dan antioksidan.

Berdasarkan penelitian Alberto dan Nadra (2006) menyatakan bahwa Ekstrak Kulit apel memiliki aktivitas antibakteri terhadap Escherichia coli ATCC 25922, Staphylococcus aureus ATCC 29213 dan Pseudomonas aeruginosa ATCC 27853. Menurut Jannata dkk.,(2014) dalam penelitiannya dengan menggunakan ekstrak kulit apel manalagi terhadap Streptococcus mutans menunjukkan bahwa ekstrak kulit apel manalagi mampu menghambat pertumbuhan dari $S$. mutans pada seluruh konsentrasi yaitu $100 \%$, 50\%, dan $25 \%$.

Berdasarkan latar belakang di atas, maka peneliti ingin mengetahui perbedaan pertumbuhan bakteri $S$. dysentriae pada berbagai konsentrasi perasan kulit apel manalagi (Malus sylvestris Mill.) secara in vitro. Hasil penelitian ini diharapkan dapat digunakannya perasan kulit apel manalagi sebagai obat herbal untuk mengobati disentri

\section{METODE PENELITIAN}

Jenis penelitian ini adalah penelitian eksperimental dengan rancangan penelitian sebagai berikut:

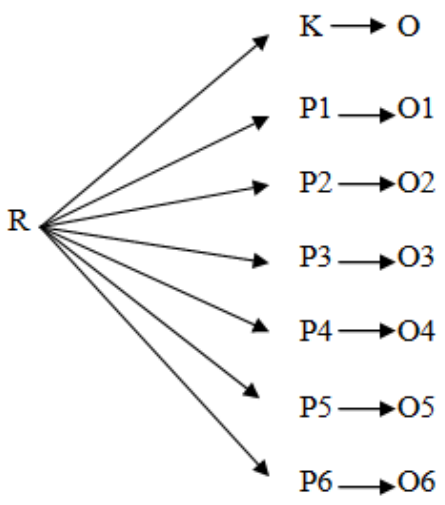

Keterangan:

$\mathrm{R}=$ Random

$\mathrm{K}=$ Kontrol

$\mathrm{P}=$ Perlakuan

Penelitian dilakukan di Laboratorium Mikrobiologi Prodi D3 Analis Kesehatan Fakultas Ilmu 
Kesehatan

Muhammadiyah

niversitas

Surabaya.

Pembuatan Perasan kulit apel manalagi dilakukan di Laboratorium Mikrobiologi Prodi D3 Analis Kesehatan Fakultas Ilmu Kesehatan Universitas Muhammadiyah Surabaya. Bakteri Shigella dysentriae berasal dari biakan murni yang diperoleh dari Laboratorium Mikrobiologi, Fakultas Kedokteran Kampus A Unair Surabaya.

Bahan yang digunakan dalam penelitian ini adalah Kulit apel manalagi, biakan murni bakteri Shigella dysentriae, media Nutrient Agar Plate (NAP), media Mac Conkey Agar (MCA), media Triple Sugar Iron Agar (TSIA), Barium Chlorida $\left(\mathrm{BaCl}_{2}\right)$, Asam Sulfat $\left(\mathrm{H}_{2} \mathrm{SO}_{4}\right), \mathrm{Pz}$ steril, $\mathrm{NaOH}, \mathrm{HCl}$ dan aquadest steril.

Pembuatan perasan kulit apel manalagi (Malus sylvestris Mill.) diawali dengan kulit apel manalagi (Malus sylvestris Mill) ditimbang sebanyak 500 gram, dicuci kulitnya sampai bersih. Kemudian diblender, setelah itu kulit diperas disaring dengan kain kasa steril. Hasil perasan kemudian disentrifuge kembali sehingga didapatkan perasan yang benar - benar jernih. Apabila masih keruh, sentrifus kembali cairan hingga jernih sehingga didapatkan konsentrasi $100 \%$.

Pembuatan perasan kulit apel manalagi dalam berbagai konsentrasi menggunakan metode serial dilution. Sediaan perasan konsentrasi $100 \%$ tanpa dicampur dengan $\mathrm{Pz}$ steril. Sediaan perasan $50 \%$ dilakukan dengan mengambil $1 \mathrm{ml}$ konsentrasi 100\% dan ditambahkan $1 \mathrm{ml} \mathrm{Pz} \mathrm{steril}$ kemudian homogenkan. Sediaan perasan $25 \%$ dilakukan dengan mengambil $1 \mathrm{ml}$ konsentrasi 50\% dan ditambahkan $1 \mathrm{ml} \quad \mathrm{Pz}$ steril kemudian homogenkan. Sediaan perasan $12,5 \%$ dilakukan dengan mengambil $1 \mathrm{ml}$ konsentrasi $25 \%$ dan ditambahkan $1 \mathrm{ml} \quad \mathrm{Pz}$ steril kemudian homogenkan. Sediaan perasan $6,25 \%$ dilakukan dengan mengambil $1 \mathrm{ml}$ konsentrasi $12,5 \%$ dan ditambahkan $1 \mathrm{ml} \quad \mathrm{Pz} \quad$ steril kemudian homogenkan. Sediaan perasan $3,125 \%$ dilakukan dengan mengambil $1 \mathrm{ml}$ konsentrasi 12,5\% dan ditambahkan $1 \mathrm{ml} \quad \mathrm{Pz} \quad$ steril kemudian homogenkan.

Pembuatan suspensi bakteri Shigella dysentriae diawali dengan Pz steril dipipet \pm sebanyak $2 \mathrm{ml}$ dan 
dimasukkan kedalam tabung reaksi.

Kemudian biakan murni bakteri

Shigella dysentriae diambil sebanyak

1 mata ose lalu dimasukkan ke dalam tabung reaksi yang berisi $\mathrm{Pz}$ steril. Tabung reaksi tersebut dihomogenkan dan dibandingkan tingkat kekeruhannya dengan standart Mac Farland I yang sudah dibuat. Apabila didapat kekeruhan suspensi bakteri Shigella dysentriae yang melebihi standart Mac Farland I maka perlu ditambahkan $\mathrm{Pz}$ steril. Tapi jika kekeruhan kurang dari standart Mac Farland I maka perlu ditambahkan dengan biakan bakteri Shigella dysentriae. Dilakukan terus menerus sampai sesuai dengan standart Mac Farland I. Setelah kekeruhan suspensi bakteri Shigella dysentriae sama dengan standart Mac Farland I dimana setara dengan jumlah bakteri $3 \times 10^{8} \quad \mathrm{CFU} / \mathrm{ml}$ kemudian dibuat jumlah bakteri $10^{3}$ CFU/ml yang akan digunakan dalam pemeriksaan sampel dengan pengenceran menggunakan $\mathrm{Pz}$ steril sampai didapatkan jumlah bakteri $3 \times 10^{3} \mathrm{CFU} / \mathrm{ml}$.

Pemeriksaan Sampel pada hari pertama diawali dengan persiapan pipet ukur $1 \mathrm{ml}$, pembakar spirtus, korek api, dan inkubator. Bahan yang digunakan adalah suspensi bakteri Shigella dysentriae dan perasan kulit apel manalagi. Masing-masing tabung diberi label sesuai dengan konsentrasinya, yaitu 100\%; 50\%; $25 \% ; 12,5 \% ; 6,25 ; 3,125 \%$; dan $0 \%$ atau kontrol. Suspensi bakteri dipipet sebanyak $1 \mathrm{ml}$ dan dimasukkan kedalam tabung reaksi yang berisi 1 $\mathrm{ml}$ perasan kulit apel manalagi konsentrasi $100 \%$ secara aseptik. Homogenkan agar suspensi tercampur sempurna. Melakukan hal yang sama pada konsentrasi 50\%; $25 \% ; 12,5 \%, 6,25 \% ; 3,125 \%$; dan $0 \%$ atau kontrol. Tujuan hal ini dilakukan agar perbandingan suspensi bakteri dan perasan sama, yaitu 1 : 1 . Lalu tutup kembali tabung dengan kapas, kemudian inkubasi pada suhu $37^{\circ} \mathrm{C}$ selama 24 jam.

Pada pemeriksaan hari kedua diawali dengan media Mac Conkey Agar (MCA) dan berbagai macam konsentrasi perasan kulit apel manalagi yang berisi bakteri dipersiapkan. Selanjutnya dilakukan pengamatan pada masing - masing tabung, apakah terjadi kekeruhan atau tidak. Setelah itu, diambil 
masing-masing konsentrasi perasan

kulit apel manalagi dan menguji kembali ke media padat Mac Conkey Agar (MCA) dengan tujuan memastikan apakah bakteri tersebut adalah Shigella dysentriae. Langkahnya diambil 1 mata ose bakteri pada konsentrasi $100 \%$ lalu ditanam ke media Mac Conkey Agar (MCA) dengan

cara menggoreskannya dipermukaan media. Lakukan kembali pada konsentrasi 50\%; 25\%; 12,5\%, $6,25 \% ; 3,125 \%$; dan $0 \%$ atau kontrol dan tanam pada masing - masing media Mac Conkey Agar (MCA). Lalu inkubasi pada suhu $37^{\circ} \mathrm{C}$ selama 24 jam.

Pada hari ketiga adalah penghitugan jumlah koloni pada media Mac Conkey Agar (MCA) yang terdapat pertumbuhan bakteri dan dicatat dalam tabel tabulasi. Setelah itu, koloni yang tumbuh ditanam pada media TSIA untuk memastikan kuman tersebut adalah bakteri Shigella dysentriae.

Pada hari keempat hasil penanaman dari media TSIA diamati dengan pembacaan leereng, dasar, gas dan $\mathrm{H}_{2} \mathrm{~S}$. Apabila lereng berwarna merah (alkali), dasar berwarna kuning (acid), gas (-), dan $\mathrm{H}_{2} \mathrm{~S}$ (-). Hal ini menunjukkan bahwa bakteri tersebut adalah Shigella dysentriae.

Data hasil penelitian yang diperoleh selanjutnya dilakukan uji ANOVA dengan tingkat kesalahan $5 \%(0,05)$.

\section{HASIL}

Hasil penelitian perbedaan pertumbuhan bakteri $S$. dysentriae pada berbagai konsentrasi perasan kulit apel manalagi (Malus sylvestris Mill.) secara in vitro dapat dilihat pada Tabel 1.

Tabel 1. Perbedaan Pertumbuhan bakteri $S$. dysentriae pada berbagai konsentrasi perasan kulit apel manalagi (Malus sylvestris Mill.) secara in vitro.

\begin{tabular}{|c|c|c|c|c|c|c|c|c|}
\hline \multirow[t]{2}{*}{ NO } & \multirow{2}{*}{$\begin{array}{l}\text { Kode } \\
\text { sampel } \\
\text { pengula } \\
\text { ngan }\end{array}$} & \multicolumn{7}{|c|}{$\begin{array}{l}\text { Jumlah Koloni Bakteri yang Tumbuh di Media } \\
\text { Mac Conkey Agar (MCA) per l mata ose } \\
\text { (CFU/ml) }\end{array}$} \\
\hline & & $0 \%$ & $\begin{array}{c}3,125 \\
\%\end{array}$ & $\begin{array}{c}6,25 \\
\%\end{array}$ & $\begin{array}{c}12,5 \\
\%\end{array}$ & $\begin{array}{l}25 \\
\%\end{array}$ & $\begin{array}{l}50 \\
\%\end{array}$ & $\begin{array}{l}100 \\
\%\end{array}$ \\
\hline 1 & $\mathrm{~A} 1$ & 29 & 28 & 25 & 20 & 0 & 0 & 0 \\
\hline 2 & $\bar{A} 2$ & 18 & 16 & 17 & 15 & 0 & 0 & 0 \\
\hline 3 & $\mathrm{~A} 3$ & 9 & 7 & 8 & 9 & 4 & 0 & 0 \\
\hline 4 & $\overline{\mathrm{A} 4}$ & 19 & 13 & 18 & 17 & 4 & 0 & 0 \\
\hline \multicolumn{2}{|c|}{ Jumlah } & 75 & 64 & 68 & 61 & 8 & 0 & 0 \\
\hline \multicolumn{2}{|c|}{ Rata - rata } & 18,75 & 16 & 17 & 15,25 & 2 & 0 & 0 \\
\hline \multicolumn{2}{|r|}{ SD } & 8,18 & 8,83 & 6,97 & 4,64 & 2,3 & 0 & 0 \\
\hline \multicolumn{9}{|c|}{ Keterangan : } \\
\hline \multicolumn{3}{|c|}{ A1 } & \multicolumn{6}{|c|}{ : Pengulangan 1} \\
\hline \multicolumn{3}{|c|}{ A2 } & \multicolumn{6}{|c|}{ : Pengulangan 2} \\
\hline \multicolumn{3}{|c|}{ A3 } & \multicolumn{6}{|c|}{ : Pengulangan 3} \\
\hline \multicolumn{3}{|c|}{ A4 } & \multicolumn{6}{|c|}{ : Pengulangan 4} \\
\hline \multicolumn{3}{|c|}{$\mathrm{SD}$} & \multicolumn{6}{|c|}{ : Standar deviasi } \\
\hline
\end{tabular}


Berdasarkan Tabel 1. diatas menunjukkan bahwa nilai rata-rata pertumbuhan koloni paling tinggi pada perlakuan kontrol yaitu sebesar 18,75 CFU/1 mata ose. Kemudian perlakuan konsentrasi terendah 6,25\% yaitu sebesar $17 \mathrm{CFU} / 1$ mata ose. Lalu perlakuan pada konsentrasi 3,125\% yaitu sebesar $17 \mathrm{CFU} / 1$ mata ose. Selanjutnya perlakuan konsentrasi $12,5 \%$ yaitu sebesar 15,25 CFU/1 mata ose. Perlakuan konsentrasi $25 \%$ yaitu sebesar 2 CFU/1 mata ose. Sedangkan pada konsentrasi $50 \%$ dan $100 \%$ tidak ada pertumbuhan sama sekali yaitu sebesar 0 CFU/1 mata ose.

Hasil tersebut di atas menunjukkan bahwa semakin tinggi konsentrasi perasan kulit apel manalagi maka pertumbuhan $S$. dysentriae tidak terjadi. Sehingga pada konsentrasi 50\% dan 100\% dikatakan sebagai daya bunuh yang paling efektif untuk $S$. dysentriae.

Berdasarkan hasil pertumbuhan koloni tersebut di atas kemudian diuji menggunakan uji ANOVA dengan taraf ketelitian 5\%. Dari hasil uji didapatkan taraf signifikan anova (p) 0,000 dan hasil uji homogenitas didapatkan taraf signifikan 0,138 dimana lebih besar dari 0,05, maka data tersebut memiliki varian sama atau homogen dan dilanjutkan dengan uji Tukey HSD untuk melihat ada tidaknya perbedaan.

Berdasarkan hasil uji anova pada tabel 4,2 menunjukkan signifikasi ( $\rho$ ) sebesar 0,000 , yang berarti $\rho$ lebih kecil dari $\alpha=0,05$, maka hipotesis diterima, jadi ada perbedaan pertumbuhan bakteri Shigella dysentriae pada berbagai konsentrasi perasan kulit apel manalagi (Malus sylvestris Mill.) secara in vitro.

Dari hasil tersebut, untuk menguji sejauh mana perbedaan antar perlakuan terhadap pertumbuhan bakteri Shigella dysentriae, dilakukan dengan uji Tukey HSD. Adapun dari hasil uji Tukey HSD dilihat pada Grafik 1.

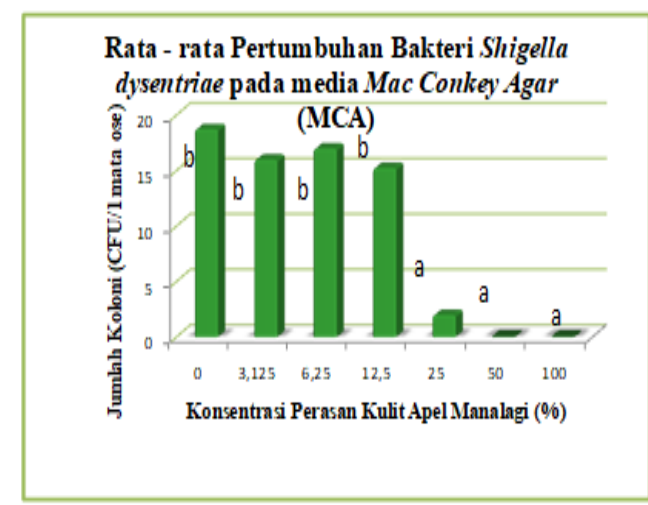

Grafik 1. Perbedaan Pertumbuhan bakteri $S$. dysentriae pada berbagai konsentrasi perasan kulit apel manalagi (Malus sylvestris Mill.) secara in vitro. 
Berdasarkan Grafik 1 di atas didapatkan perbedaan yang nyata pertumbuhan bakteri Shigella dysentriae antar perlakuan, yaitu konsentrasi 100\%, 50\%, dan 25\% dengan konsentrasi 12,5\%; 6,25\%; $3,125 \%$; dan $0 \%$.

Pada konsentrasi 100\%, 50\%, dan $25 \%$ ditandai dengan huruf a, sedangkan konsentrasi 12,5\%; $6,25 \% ; 3,125 \%$; dan $0 \%$ ditandai dengan huruf $b$. Hal ini menunjukkan bahwa pada konsentrasi 100\% berbeda nyata dengan konsentrasi $12,5 \% ; 6,25 \% ; 3,125 \%$; dan $0 \%$. Namun tidak berbeda nyata dengan konsentrasi $50 \%$ dan $25 \%$. Konsentrasi $50 \%$ berbeda nyata dengan konsentrasi 12,5\%; 6,25\%; $3,125 \%$; dan $0 \%$. Namun tidak berbeda nyata dengan konsentrasi $100 \%$ dan 25\%. Konsentrasi 25\% berbeda nyata dengan konsentrasi $12,5 \% ; 6,25 \% ; 3,125 \%$; dan $0 \%$. Namun tidak berbeda nyata dengan konsentrasi $100 \%$ dan 50\%.

Pada konsentrasi $12,5 \%$ tidak berbeda nyata dengan konsentrasi $6,25 \% ; 3,125 \%$; dan 0\%. Namun berbeda nyata dengan konsentrasi $100 \%$; $50 \%$ dan 25\%. Pada konsentrasi $6,25 \%$ tidak berbeda nyata dengan konsentrasi $12,5 \%$; $3,125 \%$; dan $0 \%$. Namun berbeda nyata dengan konsentrasi 100\%; 50\% dan 25\%. Pada konsentrasi 3,125\% tidak berbeda nyata dengan konsentrasi $12,5 \% ; 6,25 \% ; 3,125 \%$; dan $0 \%$. Namun berbeda nyata dengan konsentrasi 100\%; 50\% dan 25\%. Pada konsentrasi $0 \%$ tidak berbeda nyata dengan konsentrasi $6,25 \% ; 3,125 \%$; dan $12,5 \%$. Namun berbeda nyata dengan konsentrasi $100 \%$; $50 \%$ dan $25 \%$.

\section{PEMBAHASAN}

Hasil pengamatan jumlah koloni bakteri Shigella dysentriae menunjukkan bahwa perasan kulit apel manalagi (Malus sylvestris Mill) dapat menghambat pertumbuhan bakteri Shigella dysentriae secara optimum pada konsentrasi $25 \%$. Konsentrasi $100 \%$ dan $50 \%$ tidak dapat dikatakan menghambat tetapi dapat dikatakan sebagai kriteria efektif untuk membunuh, dikarenakan tidak ada pertumbuhan bakteri sedikitpun.

Konsentrasi $100 \%$ dan $50 \%$ memberikan efek yang optimum untuk membunuh pertumbuhan bakteri Shigella dysentriae. Dan 
untuk efektifitas terkecil kemampuan perasan kulit apel manalagi (Malus sylvestris Mill) dapat menghambat pertumbuhan bakteri Shigella dysentriae pada konsentrasi $25 \%$. Hal ini karena pada konsentrasi $25 \%$ memiliki senyawa aktif yang cukup banyak dibandingkan dengan konsentrasi dibawahnya. Kandungan senyawa dalam kulit apel manalagi (Malus sylvestris Mill) meliputi ellagic acid, chlorogenic acid, caffeic acid, tannic acid, flavonoid, quercetin (golongan flafonol), catechin, epicatechin (golongan proanthocyanidin), tannin, vitamin C, serat larut (terutama pectin), kalium, dan zink (Setiawan dkk, 2013).

Pertumbuhan bakteri Shigella dysentriae dapat terganggu disebabkan adanya suatu senyawa fenol yang terkandung dalam kulit apel manalagi (Malus sylvestris Mill). Kondisi asam oleh adanya fenol yang terkandung dapat mempengaruhi pertumbuhan bakteri Shigella dysentriae.

Kandungan dalam kulit apel manalagi yang menjadi zat antibakteri adalah polifenol. Kulit apel mengandung beberapa fitokimia turunan polifenol, antara lain katekin, kuersetin, phloridzin, dan asam klorogenik (Charde dan Chakole, 2011).

Katekin adalah golongan metabolit sekunder yang dihasilkan oleh tumbuhan dan termasuk golongan flavonoid. Sifat antibakteri pada katekin disebabkan oleh adanya gugus pyrigallol dan gugus galloil. Katekin menghambat bakteri dengan cara merusak membran sitoplasma bakteri. Kerusakan tersebut dapat mencegah masuknya nutrisi yang diperlukan bakteri untuk menghasilkan energi akibatnya bakteri akan terhambat pertumbuhannya dan mengalami kematian (Rustanti, 2009).

Kuersetin juga salah satu zat aktif golongan flavonoid. Aktivitas antibakteri kuersetin mengikat sub unit GyrB DNA girase dan menghambat aktivitas enzim ATPase. Dalam penelitian Mirzoeva dalam Jannata (2014) menunjukkan bahwa kuersetin menyebabkan peningkatan permeabilitas membran bakteri. Kuersetin juga secara signifikan menghambat motilitas bakteri (Chusnie dan Lamb, 2005). 
Phloridzin termasuk dalam kelompok dihydrochalcones, sejenis flavonoid. Flavonoid merusak dinding sel bakteri melalui perbedaan kepolaran antara lipid penyusun DNA bakteri dengan gugus alkohol pada senyawa flavonoid, sehingga dinding sel akan rusak dan senyawa tersebut dapat masuk ke dalam inti sel bakteri (Gunawan, 2009).

Asam klorogenik juga mempunyai sifat antibakteri. Asam klorogenik menghambat enzim tertentu yang terlibat dalam sintesis asam lemak bakteri. Asam klorogenik juga secara signifikan meningkatkan permeabilitas membran plasma bakteri yang mengakibatkan kebocoran isi sitoplasma termasuk nukleotida (Karunanindhi et.al., 2012).

\section{Chlorhexidine mengandung} fenol yang memberikan efek bakteriostatik pada kadar 0,2-1\%, bersifat bakterisida pada kadar 0,4$1,6 \%$, dan bersifat fungisidal pada kadar diatas 1,3\%. Kandungan bahan dasar chlorine merupakan desinfektan tingkat tinggi karena sangat aktif pada semua bakteri, virus, fungi, parasit, dan beberapa spora (Agusmawanti, 2007).
Kulit apel banyak mengandung senyawa flavonoid yang bersifat polar sehingga lebih mudah menembus lapisan peptidoglikan yang bersifat polar pada dinding sel bakteri (Dewi, 2010). Senyawa antibakteri yang masuk tersebut akan mengakibatkan tekanan osmotik di dalam sel lebih besar, sehingga menyebabkan lisis (Kusmiyati dan Agustini, 2007).

\section{SIMPULAN DAN SARAN}

Berdasarkan hasil penelitian yang telah dilakukan dapat disimpulkan bahwa perasan kulit apel manalagi berpengaruh terhadap pertumbuhan koloni Shigella dysentriae.

Konsentrasi yang efektif dalam menekan pertumbuhan koloni Shigella dysentriae pada konsentrasi $50 \%$ dan $100 \%$. Sedangkan konsentrasi yang efektif menghambat pertumbuhan koloni pada konsentrasi $25 \%$ dengan pertumbuhan bakteri terkecil rata - rata sebesar 2 koloni/1 mata ose.

Beberapa saran yang mungkin bermanfaat bagi peneliti selanjutnya yaitu perlu penelitian lebih lanjut untuk mengetahui kemampuan kulit 
apel manalagi dalam menghambat

pertumbuhan mikroflora lain yang

patogen terhadapa manusia.

\section{DAFTAR PUSTAKA}

Afzadi MA. Genetic and biochemical properties of apples that affect storability and nutritional value. Introductory Paper at the Faculty of Landscape Planning, Horticulture and Agricultural Science. Swedish: SLU; 2012. p. 3

Agusmawanti, P. "Perbandingan Daya Antibakteri Kumur Rebusan Gambir (Uncasia gambir) dengan Chlorhexidine 0,2\% Terhadap Jumlah Koloni Bakteri Saliva". J. Maj. Ilmiah Sultan Agung. Vol. 49 (2007) 1-9.

Aini MN. 2015, Aneka Buah Berkhasiat Obat. Yogyakarta : Real Books

Asromedika, 2011. TrimetoprimSulfametoksazol

(Cotrimoxazole).

http;//asromedika.blogspot.co.i d/2011/08/Trimetoprim-

Sulfametoksazol.html?=1

Charde, M. S., Ahmed A., \& Chakole, R. D. "Apple Phytochemicals for Human Benefits". Int. J. Pharm. Res. Vol. 1 (2) (2011) 1-8.

Chusnie, T. P. T. \& Lamb, A. J. "Antimicrobial Activity of Flavonoid". Int. J. Antimicrob. Agent. Vol. 26 (2005) 343-356.

\section{Depkes, 2010, Pedoman Pemberantasan Penyakit Diare. Mentri Kesehatan Republik Indonesia. Diakses 28 April 2016 Available from : http://www.depkes.go.id/downl oads/SK1216-01.pdf}

Depkes, 2011, Profil Kesehatan. Diakses 28 April 2016, http://www.depkes.go.id/folder /view/01/structure-publikasipusdatim-profil-kesehatan.html

Dewi, F. K. "Aktivitas Antibakteri Ekstrak Etanol Buah Mengkudu (Molinda citrifolia, Linnaeus) Terhadap Bakteri Pembusuk Daging Segar". Skripsi. Surakarta: Fakultas Matematika dan Ilmu Pengetahuan Alam Universitas Sebelas Maret (2010)

Djajaningrat H \& Misnadiarly. 2014. Mikrobiologi untuk klinik dan Laboratorium. Jakarta : PT Rineka Cipta

Giomaro G, Karioti A, Bilia AR, et al. Polyphenols profile and antioxidant activity of skin and pulp of a rare apple from marche region (italy). Chemistry Central Journal; 2014;8:1

Gunawan, I.W.A. "Potensi Buah Pare (Momordica Charantia L) Sebagai Antibakteri Salmonella typhimurium". Skripsi. Denpasar: Program Studi Pendidikan Biologi Fakultas Keguruan dan Ilmu Pendidikan Universitas Mahasaraswati (2009). 
Haryadi, 2012, Disentri basiler.

Diakses 25 April 2016, http://digilib.ump.ac.id/files/dis k1/2/jhptump-a-E.har-76-1babi.pdf

Heneman K, Zidenberg-Cherr S. Some facts about flavonols. Nutrition and Health InfoSheet for Health Professionals: 2008: 1

Hidayat, A.Aziz Alimul. 2010. Metode Penelitian Kesehatan. Health Books Publishing, Surabaya

Jannata RH, Gunadi A, Ermawati T. Daya antibakteri ekstrak kulit apel manalagi (Malus sylvestris Mill.) terhadap pertumbuhan Streptococcus mutans. E-Jurnal Pustaka Kesehatan; 2014;2: 24,6

Jawetz, E, Melnick, L.L, Adelburg, E. A.2008. Mikrobiologi Kedokteran. Jakarta : Penerbit Buku Kedokteran EGC

Karunanindhi, A., Thomas, R., Belkum, A., \& Neela, V. "In vitro anti-bacterial and antibiofilm activities of chlorogenic acid against clinical isolates of Stenotrophomonas maltophilia including the trimethoprim/sulfamethoxazole (TMP/SMX) resistant strain". BioMed Research Int. Vol. 2013 (2012) 1-24.

Kayser FH, Bienz KA, Eckert J, Zinkernagel RM. Color atlas of medical microbiology. New York: Thieme; 2005. p. 363
Kementerian Kesehatan, 2013. Profil Kesehatan Tahun 2012. Diakses 30 April 2016, http://www.depkes.go.id/resour ces/doemnload/profil/PROFIL KES_PROVINSI_2012/15_Pr ofil_Kes.Prov.JawaTimur_201 2.pdf

Kusmiyati dan Agustini, N. "Uji Aktivitas Senyawa Antibakteri dari Mikroalga Porphyridium cruentum". Biodiversitas Vol. 8 (1) (2007) 4853.

Nathania, Devi . 2008. Shigella dysentriae. Hal 1-2, diakses 30 april 2016 , http://mikrobia.files.wordpress. $\mathrm{com} / /$

Puspitasari, 2012. Muthuswamy, S,. dan Rupasinghe, H. P. V. "Fruit phenolics as natural antimicrobial agents: Selective antimicrobial activity of catechin, chlorogenic acid and phloridzin". Journal of Food, Agriculture \& Environment. Vol.5 (3\&4) (2007) 81-85

Redha. Flavonoid: struktur, sifat antioksidatif dan peranannya dalam sistem biologis. Jurnal Belian: 2010;9: 197

Rustanti, E. "Uji Efektivitas Antibakteri dan Identifikasi Senyawa Katekin Hasil Isolasi dari Daun Teh (Camellia sinensis L. var. Assamica". Skripsi. Malang: Fakultas Sains dan Teknologi Jurusan Kimia Universitas Islam Negeri Malang (2009). 
Setiawan D \& Felix A. 2013, Fakta

Ilmiah Buah dan Sayur, Jakarta

: Penebar Swadaya Grup

Soedarto. 2009. Penyakit Menular Indonesia. Jakarta : CV Sagung Seto

Sufrida Y, Irlansyah, Edi J, Mufatis W. Khasiat dan manfaat apel. Jakarta: Agro Media; 2007, pp. 22-30
Sumono A, Wulan A. The use of bay leaf (Eugenia polyantha Wight) in dentistry. Dental Journal: 2008;41: 148-9

Swastika A, 2014. Khasiat Buah dan Sayur Tumpas Segala Penyakit. Yogyakarta : Shira Media

Wulandari A. Daya antibakteri ekstrak buah apel manalagi terhadap bakteri Salmonella thyposa. Jurnal Healthy Science AAKMAL: 2012;2: 13. 